\title{
Development of sugar palm-based products: a community project
}

\begin{abstract}
The project described in Chapter 12 is concerned with the development of products from the sugar palm (Arenga pinnata) tree (locally known as Enau) under the UCTCNBOS community grant funded by the Ministry of Higher Education, Malaysia. This community project was carried out in collaboration with the Jawatan Kuasa Kemajuan dan Keselamatan Kampung (JKKK), Kampung Kuala Jempol, Bahau, Negeri Sembilan. Twelve products including sugar palm syrup, sugar palm sugar blocks, sugar palm granular sugars, sugar palm fruits, sugar palm vinegar, sugar palm starch and other sugar palm fibre-based products like brooms, general cleaning brushes, bottle cleaning brushes, ropes, raw fibres, and roofs have been developed. The main objective of this project was to help the community to develop and commercialize sugar palm products, which in turn will improve their socio-economic level. Knowledge transfers of various methods and technologies have been conducted through a series of demonstrations. Two of these products have been registered under trademarks and commercialization efforts have commenced. The community members were very excited with this project, as 'wastes' that are present around them have been converted into 'wealth'.
\end{abstract}

Keyword: Sugar palm; Sugar palm product; Sugar palm tree; Arenga pinnata 
